\title{
The Model of Management of the Masela Block Based on People's Welfare in Maluku
}

\section{Jarot Digdo Ismoyo}

Faculty of Law, Universitas Hein Namotemo, Halmahera Utara, Indonesia

Email Coresponden: ismoyojarot@gmail.com

\begin{abstract}
This research is motivated by the wealth of Indonesia, which has a fertile layer of land and there are very large deposits of minerals, oil and gas, this potential should ideally be managed for the welfare of the people. This research was aimed at explaining and analyzing the failure of mining management in Indonesia and the management model of the Masela Block based on the people's welfare in Maluku. This study uses normative legal research methods with data sources in the form of primary and secondary legal materials. The results showed that the discovery of the Masela Block gave the local government an opportunity to actively participate in mining management and that the oil and gas rich Masela Block to be exploited was a golden opportunity for the Maluku local government to actively participate in the oil and gas mining sector in an effort to improve people's welfare.
\end{abstract}

Keywords: Mining; Masela Block; Maluku.

\begin{abstract}
Abstrak
Penelitian ini dilatarbelakangi oleh kekayaan Indonesia yang memiliki lapisan tanahnya subur dan terdapat endapan mineral, minyak dan gas bumi yang sangat besar, potensi ini idealnya harus dikelola untuk kesejahteraan rakyat. Penelitian ini dilatbertujuan untuk menjelaskan dan menganalisa kegagalan pengelolaan pertambangan di Indonesia dan model pengelolaan Blok Masela berbasis kesejarteraan rakyat di Maluku. Penelitian ini menggunakan metode penelitian hukum normatif dengan sumber data berupa bahan hukum primer dan sekunder. Hasil penelitian menunjukkan bahwa penemuan Blok Masela memberi kesempatan pemerintah daerah untuk berpartisipasi aktif dalam pengelolaan pertambangan dan Blok Masela yang kaya akan minyak dan gas bumi yang akan diekploitasi merupakan kesempatan emas bagi pemerintah daerah Maluku untuk berpartisipasi aktif dalam sektor pertambangan migas dalam upaya meningkatkan kesejahteraan rakyat.
\end{abstract}

Kata Kunci: Pertambangan; Blok Masela; Maluku. 


\section{Introduction}

Indonesia is an abundant region, in terms of natural resources. The nation situated on the equator possesses a range of natural resource resources such as forests, forestry, farmland, maritime resources, oil and gas, as well as numerous minerals found in the earth 's body and under the sea that are scattered almost throughout all regions. The natural resources is the archipelago's draw for foreign nations. Originally, Europeans were going around the globe searching for a plague drug that caused great death in Europe. One of the essential ingredients is nutmeg, which is much-needed but is not available in mainland Europe. It is this natural wealth that draws many nations to own these commodities, process and manage them. Initially the arrival of Europeans was merely to trade with the archipelago kingdoms.

At first foreign nations came to trade but the goal was to exploit the natural resources of Indonesia in view of the big income. The approach used is that of colonialism. Colonialism in the archipelago began in 1619, marked by VOC troops (Verenigde Oost Indische Compagnie), a Dutch trading company whose goal was to monopolize the archipelago's spice trade under Jan Pieterzoon Coen 's leadership and take Jayakarta (Batavia). The VOC was declared bankrupt on 1 January 180o, and dissolved. Afterwards all the property of the VOC was taken over by the Dutch government. The Dutch colonized Indonesia until the 8th of March 1942 (Nanik Trihastuti, 2013: 93). Dutch gains from soil fertility are very high in managing spices and agricultural resources with a Stelsel system, to reap income of up to hundreds of millions of Florins. Profit is more than 100 percent per annum, while share price rises to 1.080 percent of its nominal value (Mohammad Hatta, 2015: 338). Soekarno stressed that trillions of rupiahs directly cost the results of international capital companies that were shipped from Indonesia from coffee, tea, tobacco, sugar or rubber annually. In short, the capital exported from Indonesia is at least 1500,00o,ooo per annum (Soekarno, 1951: 50). A phenomenal salary in those days.

The capacity of natural riches that lies under the earth and under the sea. Most rock and mineral reserves, and natural gas reserves. This ability can be turned into welfare if properly handled by a mining company, which is the task of exploiting the natural mining resources (minerals) found in the earth. Mining operations exist in various stages such as phases of mineral or coal research, management and exploitation, including general investigations, exploitation, feasibility studies, construction, mining, processing and refining, transport and post-mining sales (Salim HS, 2012: 15). It must be noted that the mining sector has unique characteristics that require large quantities of resources, use new technologies, are carried out by specialists, are at high risk, yields are sluggish and are prone to changes in situation. Each of these characteristics are possessed only by developed countries in terms of both the availability of skilled human capital, the mastery of high-tech and the availability of funds to operate a mining sector. With the aforementioned characteristics, it is a challenge for the citizens of Indonesia to handle mining, despite specific limitations. First, there are too few educated and skilled Indonesians capable of executing policies to enable a 
class of indigenous entrepreneurs to grow and accelerate economic recovery. Second, foreign-owned companies and Chinese community groups still dominate the modern economic sectors, while natives lack the strong resources and entrepreneurial skills required to compete with them economically (Andrian Sutedi, 2011:1).

The potential of oil and gas wealth in the Arafura Sea, Maluku, which is called the Masela Block, was discovered in the 200o's. Despite being located in the middle of the sea, President Joko Widodo decided in 2016 to explore the Masela Block that was carried out on land (on shore). The management of the Masela Block is one of 37 priorities in the National Strategic Project (PSN), as set out in Presidential Regulation No. 58 Year 2017 on Amendment to Presidential Regulation No. 3 Year 2016 on the acceleration of the implementation of the National Strategic Project. The government is currently targeting the revision of the Masela Block Development Plant to be done entirely by Inpex Corporation and Shell Indonesia by the end of 2018 so its construction is in line with the multiplier impact the government wants for the region. Now the government is starting to prepare a master plan that involves aspects of improving local community engagement to get involved in managing oil and gas fields. One way is through collaboration with the University of Pattimura (Jarot Digdo Ismoyo: 2018: 386 ).

The decision by the government to explore and develop the Masela Block is becoming an significant study given that foreigners regulated oil and gas mining during Indonesia 's independence. In the old order period, despite the constraints of human resources, lack of capital and poor technical dominance, the government had not yet agreed on mining management. And in the new order period, by welcoming foreign investment, the management of the mining industry, including oil and gas, and mineral and coal mining, was opened wide. International mining investment is based on a relationship, called a labor contract. As a result of the numerous facilities offered to foreign investors, foreign companies explore and develop various mining materials through foreign investment, while state participation through PT Pertamina (Persero) is unimportant. The following data comes from the Upstream Oil and Gas Business Activities Implementing Agency (BP Migas), as quoted in The Global Review (Global Review, 2012).

The exploitation of natural mining resources is not linear with the rise of social welfare. The mining sector's state revenue is very small, as can be seen from holding shares in mining companies that are below 10 percent, while the divestment of shares has not been realized. Foreigners also control the upstream to downstream markets, so that state revenues intended to establish stability and growth have not yet been achieved. At the other hand, the international investors gain huge income. It is an irony of a nation rich in natural resources but with a high level of deprivation in the population. The question is how to turn mining capacity into real welfare.

People often ask why Indonesia, rich in natural resources like mining, doesn't automatically turn into a prosperous and prosperous country? 
Theoretically the abundance of natural resources impacts rapid economic development as capital becomes a developed economy. But reality is revealing the opposite. Countries that are rich in natural resources are, in fact, at the level of developing (poor) countries, whereas countries that lack natural resources are actually racing to develop or become rich. This trend is demonstrated in many studies, including those carried out by Richard Auty (1993, 2001), Sachs and Warner (1995, 2001), Jeffrey A. Frankel (2012) showing that countries rich in natural resources are becoming poor (developing) countries, whereas a world lacking natural resources is increasingly becoming a developed country. Richard Auty initially coined the term curse on natural resources to explain this confounding phenomenon. With the econometric literature Sachs and Warner (1995) indicate that economic reliance on oil and minerals is associated with sluggish economic growth. In a subsequent study by Sachs and Warner (2001), which extended earlier studies, evidence showed that countries rich in natural resources appear to rise more slowly than countries without natural resources. Even this finding is not easily clarified by variables or in other ways in evaluating the association between resource abundance and welfare (Frankel, Jeffrey A, 2012:3). Based on the explanation above, the question in this research will be how is Indonesia able to escape from natural resource curse?

\section{Research Methods}

This study uses a juridical-normative method using the statute approach. Analysis and evaluation are based on literature studies on primary and secondary legal materials. The main primary laws used are the 1945 Constitution of the Republic of Indonesia; Law Number 22 of 2001 concerning Oil and Gas; Law Number 23 of 2014 concerning Regional Government; Law Number 33 of 2004 concerning Financial Balance between the Central Government and Regional Governments, Government Regulation Number 35 of 2004 concerning Upstream Oil and Gas Business Activities; Government Regulation Number 36 of 2004 concerning Oil and Gas Downstream Business Activities; Government Regulation Number 55 Year 2005 concerning Balance Funds, Government Regulation Number 54 Year 2017 concerning Regionally Owned Enterprises and Regulation of the Minister of Energy and Mineral Resources Number 37 of 2016 concerning Participating Interest $10 \%$ (Ten Percent) in Oil and Gas Working Areas. Secondary data obtained from the results of previous publications and research. The results of the next literature study are presented descriptively. Legal materials are collected and inventoried, then processed and studied in depth so as to obtain a complete picture of the legal issues studied (Peter Mahmud Marzuki, 2019: 184).

\section{Discussion}

\section{The Failure of Mining Management in Indonesia}

Indonesia is also facing a "curse on natural resources" as the natural resources curse put forward by experts. Abundant natural wealth does not necessarily make a rich and prosperous nation. There are many factors which 
affect internal as well as external states. Internally the government's poor performance has a huge effect on state revenue. A study of 58 countries on the natural resource governance index (RGI) reveals that income from these countries' extractive industries totaled \$2.6 trillion in 2010. Owing to error management and corruption, the inability to control natural resource resources (SDA) There are 26 countries rich in natural resources that do not get the full benefits due to the poor governance of the extractive industry. As a result, more than 300 million people survive on less than two dollars a day (or 50 per cent of the total population of 26 countries). Meanwhile, the population with very low incomes is only an average of 10 million people (or 7 per cent of the population) in countries rich in natural resources but with weak governance results. (Patrick, Heller, and Poppy Ismalina, 2012).

The inability to use natural resources from mining is evident in the statement by Abraham Samad, head of the Corruption Eradication Commission (KPK), said that the capacity of natural resources in the oil and gas sector is not handled optimally. In addition to tax collecting businessmen, the Indonesian oil and gas industry is dominated largely by foreigners. KPK has found a potential loss of Rp's state revenue. 7.200 trillion royalties which are not paid annually to the Government. That is because the oil and gas companies are not meeting the deals negotiated. Unpaid royalties hit Rp when combined with mineral and coal mining market. 20,00o trillion annually. Through this estimate the income of the Indonesian people per month will exceed $\mathrm{Rp}$ if distributed to all citizens. 20 million (D. Susanto, Agung Marsudi, 2016: xvi).

President of the Confederation of the Indonesian Oil and Gas Workers Union (KSPMI) Faisal Yusra assessed Indonesia is a paradise for foreign mining investors who control up to $75 \%$ of mining. The mastery of oil and gas mining contracts until 2013 (Okezone.com, 2013) is as follows:

Table 1

Mastery of Oil and Gas Mining Contracts until 2013

\begin{tabular}{|l|c|}
\hline Contract Holder & Total \\
\hline Asing & $\mathbf{1 2 0}$ \\
\hline Nasional & $\mathbf{2 8}$ \\
\hline Betwen Asing - Nasional & $\mathbf{7 7}$ \\
\hline
\end{tabular}

Source: Ministry of Energy and Mineral Resources

For the 225 contracts for oil and gas blocks, the composition indicates global domination in the oil and gas mining market. Research conducted by Agung Marsudi D. Santoso, (Agung Marsudi D Susanto, 2016: xiv) shows that there were 263 oil and gas blocks in Indonesia during 2014-2019 which had the following management:

Table 2

Control of the Oil and Gas Block in 2014-2019

\begin{tabular}{|l|c|}
\hline Block Amount & Total \\
\hline Already Production & 79 \\
\hline Foreign Management & 55 \\
\hline Eksplorasi & 180 \\
\hline
\end{tabular}

Source: Ministry of Energy and Mineral Resources 
This data reveals that 55 out of 79 blocks of oil and gas or 70 per cent are operated by multinational firms such as Chevron, Total, Inpex, Exxon Mobile, British Petroleum, etc. The number and new exploration activities will continue to grow. Similarly, international investment in the mineral and coal mining subsectors (The Global Analysis, 2012 ) reveals the following control patterns:

Table 3

Percentage of Foreign Ownership of Mining until 2012

\begin{tabular}{|l|c|}
\hline \multicolumn{1}{|c|}{ Mine Type } & Foreign Mastery \\
\hline Petroleum and natural gas & $85 \%$ \\
\hline Minerals (gold, silver and copper) & $95 \%$ \\
\hline Coal & $85 \%$ \\
\hline
\end{tabular}

Source: Ministry of Energy and Mineral Resources

The data shows that the international domination dominance of the mineral and coal mining sector is very high ranging from 85 per cent to 95 per cent, while the national influence is very weak. In Indonesia, foreign investment is in full charge of mineral mining. It is also a question of why Indonesia is not a established, stable and productive country, with such abundant natural resources. Yes, Indonesia is included in the group of poor countries (developing countries), after 70 years of independence. In 2010 the popular US business journal Global Finance published the ranking of 182 countries in the world based on the per capita gross domestic product (GDP) rates from the poorest countries to the world's richest. The method used to determine the wealth of the country is to measure the living standards of the population of one country as a whole, using per capita gross domestic product ( GDP) based on parity or mutual balance of purchasing power. Indonesia ranks 122nd with a GDP per capita of US\$ 4,380 or Rp 39.4 million per year, based on ranking data from 182 countries. Indonesia is recognized as a country with abundant wealth of natural resources, including plantations, mining, and oil. This country also has a relatively large population, more than 230 million people (Heri Susanto, 2010).

While blessed with abundant natural resources, it has no major effect on state revenues due to the government's poor results. A study of 58 countries on the natural resource governance index (RGI) reveals that the profits of extractive industries in those countries totaled \$2.6 trillion in 2010. Nevertheless, due to mismanagement and corruption, many countries simply lost opportunities to take advantage of natural resource resources. The survey shows that 26 countries that are rich in natural resources struggle to get the maximum benefit from natural resource wealth due to weak regulation of the extractive sector. More than 300 million people survive on less than two dollars a day in those 26 countries (or 50 per cent of the total population of 26 countries). Meanwhile, the population with very low incomes is only an average of 10 million people (or 7 per cent of the population) in countries rich in natural resources but with good governance results. Heller, Patrick and Ismalina the Poppy, 2016). 


\section{The Model of Management of the Masela Block Based on People's Welfare in Maluku}

President Joko Widodo had acknowledged the inability to control the mining industry. With the Nawa Cita concept, Indonesia aims to manage mining wealth in accordance with the Republic of Indonesia 's ideals of independence for the welfare of the people. The legal principle has in reality been conceived as the state constitution by the founding fathers who were conceived in the Republic of Indonesia Constitution of 1945 (1945 Constitution). The new era of the government of President Joko Widodo restored the control of mining according to the Constitution of 1945. The constitution has been used as a guideline against the burden of natural resources by the effective and fair allocation of natural resources for social welfare. To this end, the State and all the elements of the country will strive to uphold the constitution and its elaboration in legislation capable of preventing the reversal of policies that disregard or weaken the constitutional provisions. Article 33 of the Constitution of 1945 as an economic constitution needs to be reexamined in terms of its purpose and ideology in solving national problems.

Economic democracy is a basic reaction to colonialism imposed by the Dutch colonialists in Article 33 of the 1945 constitution. Article 33 of the Constitution of 1945 constitutes a policy of mining law which regulates the objectives to be achieved with the current (applied) legal framework and what methods (mechanisms) are considered the best (effective) to achieve those objectives; Satjipto Raharjo, 2000: 352). Muh. Mahfud and M.D. State the discussion of legal policy with a view to achieving the country 's objectives through a national legal framework requires at least three things: first, state policy (official line) on laws to be adopted or not implemented in order to achieve the State 's objectives; second, political, economic , social , cultural (poleksosbud) context on the birth of legal products; third, law Mahfud MD, 2014: From the hermeneutic point of view, the sense of state control over production resources that are important to the country and control the livelihoods of many people who are used for the greatest prosperity of the people is the authority of the state to regulate downstream utilization of energy source management by the government or the state administration. The state is an entity with the highest authority or power to be able to take care of all collective interests to prosper. In addition, state authority must be reflected in sectoral natural resource regulations (Marsel Selamat, 2018: 108). Of this purpose, the usage of natural resources must be synchronous with all laws and regulations, must not deviate or overlap. Deviations from this article have a very significant effect on the management of the mining sector that is centralized or entrusts the management of mining to big businessmen / investors by setting the state aside.

Article 33 of the Constitution of 1945 is laid down in Law $\mathrm{n}^{\circ} 22$ of 2001 on oil and gas. Article 4(1) Oil and gas as strategic non-renewable natural resources within the jurisdiction of Indonesian mining are State-controlled national 
properties. Therefore, the government will serve as the oil and gas production operators and entrepreneurs. State-owned enterprises (BUMN) will do the upstream sector in the form of exploration and extraction. Government Regulation No 35/2004 relating to Upstream Oil and Gas Business Activities assigns duties to SOEs to carry out exploration and mining operations, namely PT Pertamina (Persero). While the Government Regulation No. 36 of 2004 relating to Oil and Gas Downstream Business Activities in the form of processing, transport, storage and trade may be submitted to PT Pertamina (Persero) or may be submitted to regional owned companies (BUMD) and/or cooperatives. For this reason, both the central and regional governments in the oil and gas mining area need national readiness. Local governments are expected to plan themselves to form and maintain BUMDs as provided for in Article 331 of Law No. 23 of 2014 on State Government in accordance with Government Regulation No. 54 of 2017 on Local-Owned Enterprises.

The application of the welfare state principle to economic activities is very significant and appropriate for achieving the goals of the government. In the Constitution of 1945, this principle is evident in Article 33 paragraph (2) where the state must regulate the branches of production which are essential to the state and which control the lives of many citizens. The article authorizes the state to take part in economic activities by introducing branches of production which can be classified as essential, critical and strategic. The State 's position is required so that the branches of production in the free market system do not just fall into the hands of individuals. For this purpose, the state must consciously assume the role and conduct the branches of production in the form of a special legal entity called a State-Owned Enterprise (BUMN), with the aim of people's welfare. Therefore, it must be clarified that the mineral rights (mineral rights) in the government authority as a representative of the state occur in the mining management system. The management is handed over to legal entities named State-Owned Enterprises (BUMN), Regional-Owned Enterprises (BUMD) or cooperatives during implementation. The transfer to BUMN of all matters relating to the operation of mining authority is as a state representative (geopolitical dimension) and is carried out in compliance with the standards of industry (geo-economic dimension). It is expected to cause and improve the welfare of the people, especially Maluku, with the management of the Masela block.

Technically, local government involvement in mining management is governed in the Ministry of Energy and Mineral Resources (ESDM) Regulation No. 37 of 2016 on a 10 percent (ten percent) Oil and Gas Working Area Participating Interest Provisions. This legislation provides incentives for the regions to engage effectively in managing the Masela block for the benefit of the Maluku people. Via BUMD, local authorities will invest in oil and gas exploration in their regions. The prerequisite is that the BUMD must be a corporation owned by the region or a Limited Liability Company comprising 99 percent (ninety-nine percent) of its shares, held by the region and established on the basis of regional regulations. For this involvement, the regions are now 
dependent not only on profit-sharing funds based on the 2004 Law No. 33 on the Financial Balance between the Central Government and Local Governments in accordance with the 2005 Government Regulation No. 55 on Balance Funds.

Therefore, there are no statutory restrictions to the Masela block management. The aim of the welfare of the people can be achieved, judging from the politics of law. The translation is accurate in the Law on Oil and Gas, the Law on Local Governments, the Law on Fiscal Balance between the Central Government and Regional Governments in terms of the order of the state regulations. Policy rules for the Energy and Mineral Resources Minister 's oversight have also been in line to help the country 's goals.

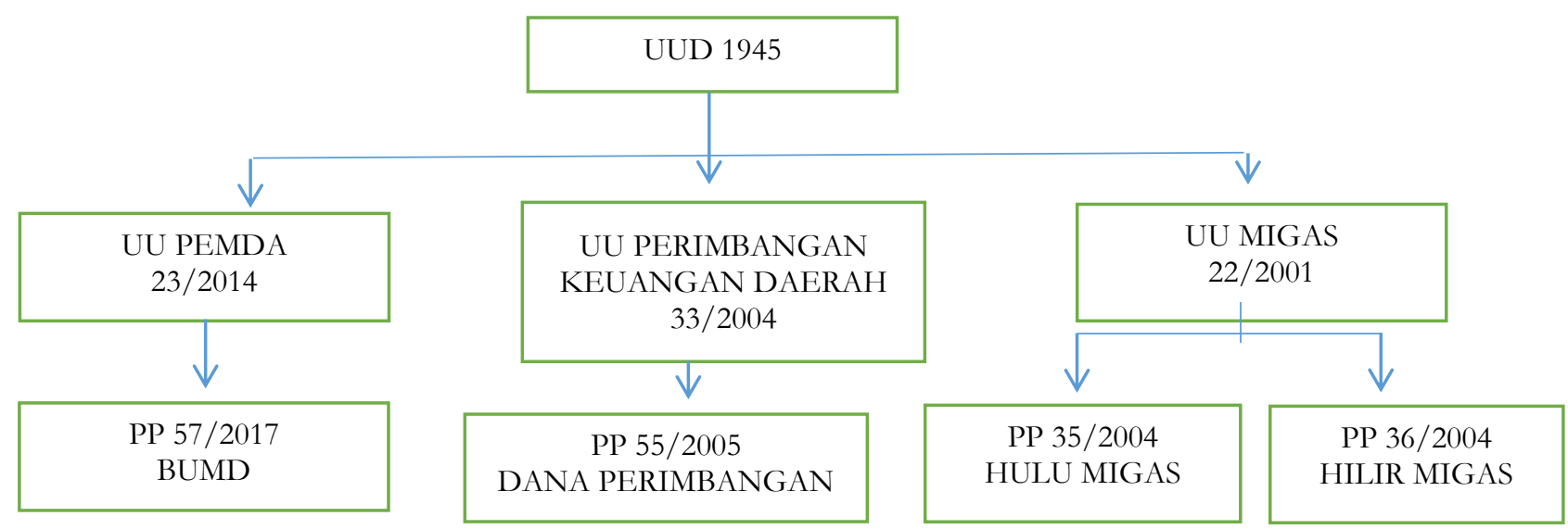

Now the problem is can local governments manage mining based on available opportunities? Maluku Province is one of the island-based provinces in Indonesia with an area of 712,479, $65 \mathrm{~km} 2$ consisting of sea area of $658,294.69$ $\mathrm{km} 2(92.4 \%)$ and land area of 54,185 km2 (7.60\%). Maluku Province consists of 1,340 islands, with a coastline length of $10,630.10 \mathrm{~km} 2$, and only has 4 large islands (Seram, Buru, Yamdena and Wetar) the rest are small islands that form groups of islands. Of the many islands that are owned, only $162(12 \%)$ of the islands have a population of the total number of islands. The location of the Masela block, located off the coast of the Arafura Sea - Maluku waters, is directly adjacent to Australia in the province of Maluku. The contract was signed on 16 November 1998 for 30 years (Anton A. Lailossa, 2020: 2). Masela Block has an investment value: Rp. 252-28o Trillion (19.8 Billion USD). The period of construction work between 2022 - 2027 reached US \$ 7.5 billion, equivalent to 104.25 tirliun. Furthermore, the production process in $2027-2055$ amounted to US \$ 146.1 billion or around $\mathrm{Rp}$ 2,030 trillion (Marwan Batubara, 2020:3). The area of the mine is $2,503.3 \mathrm{Km} 2$. Participating Interest holders are Japanese Inpex Corps by $65 \%$, Dutch Shell UOS by 35\%, including Maluku by $10 \%$. The Masela block is operated by Inpex Masela Ltd (Djufri Rays Pattilouw, 2020: 5). thus the Maluku provincial government must prepare itself to take part in the Masela Block oil and gas mining. The necessary preparations include forming and strong BUMD management skills, preparing a 10\% Participating Interest (around 25-28 Trillion), 
preparing trained and skilled human resources (around 73,00o people), preparing high-tech (hi-tech).

It is not easy to navigate the oil and gas production market. It needs major money, high-tech expertise, human resource preparation and a strong BUMD. International parties can usually meet those criteria. The constitution and regulations governing it, however, have specifically opened up opportunities for regional involvement in mining administration. Here the Masela Block management challenge lies. Behind these challenges, the Masela Block's downstream business activity promises several positive factors including enhancing regional energy security, increasing the human development index, accelerating development and the regional economy that contributes to improving the welfare of the Maluku people and the surrounding area in particular. The Presidential Directive on the use of local content (HR, raw materials, supporting materials) definitely becomes a driving influence in the form of opening up employment opportunities (around 73,000 workers), rising support for economic activities (hotels , restaurants, banks, etc.), increasing household income, raising the economic rate for the citizens of Maluku Province. If this opportunity is used effectively, there is no question that by rising unemployment and poverty, Maluku Province will experience an increase in welfare.

To meet this goal, both the legislation and the socio-cultural society have to be prepared by the Maluku regional government. The regulations drafted include policies on the readiness of skilled human resources, the readiness to protect the environment as a result of mining, minimizing land disputes and shifting the community's social cultural values. Maluku local government needs to build a socio-cultural environment that is conducive and open to economic development and investment. With this readiness the area of Maluku will be able to optimally benefit while mitigating its negative impacts.

\section{Conclusion}

Indonesia is able to extricate itself from the burden of natural resources based on the Constitution of 1945. State regulation and management of oil and gas production are a part of state sovereignty manifestation. The federal government, provincial governments, and cooperatives conduct oil and gas extraction. Economic Constitution Article 33 of the Constitution of 1945, as drawn up in the Law on Oil and Gas Mining, the Law on Local Governments and other Government Regulations, gives local governments opportunities to participate in oil and gas mining activities. The law does not pose any hurdles. In addition, the Provincial Government of Maluku has a golden opportunity to participate in the oil and gas mining sector with a 10 percent (ten percent) participating interest in the Masela Block through BUMD or a company whose area owns 99 percent (ninety nine percent) of the shares. The Masela Block management will improve the welfare of the Maluku people by absorbing workers, growing economic development, rising household income and skilled culture of work. For this purpose, the regional government of Maluku must plan well the human 
resources, create a formidable BUMD, environmental regulations and the community's socio-cultural regulations.

\section{References}

Anis Siti Hartati and Marita, "The Performance of Miners in Old Oil Wells in Coal Potential Area (Study: Traditional Oil Miners in Wonocolo, Bojonegoro, Indonesia)", International Journal of Social Science and Humanity, Vol. 7, No. 12, December 2017.

Gina Lova Sari, Yulinah Trihadiningrum, Ni'matuzahroh, "Petroleum Hydrocarbon Pollution in Soil and Surface Water by Public Oil Fields in Wonocolo Sub-district, Indonesia”, Journal of Ecological Engineering, Volume 19, Issue 2, March 2018.

Qomarudin Helmy and Edwan Kardena, "Petroleum Oil and Gas Industry Waste Treatment; Common Practice in Indonesia", J Pet Environ Biotechnol, Volume 6, Number 2 (2015)

Abdul Kadir Jaelani, "Politik Hukum Putusan Mahkamah Konstitusi Nomor 36/PUU-X/2012 Tentang Pembubaran BP MIGAS: Upaya Mengembalikan Kedaulatan Negara Menuju Perlindungan HAM", Jurnal Panggung Hukum, Volume 1, Nomor 1 Tahun 2015.

Shinta Hadiyantina, Nandaru Ramadhan, "The Emergency of Authority on the Supervision of Old Wells Mining Policy in Indonesia", Advances in Economics, Business and Management Research, Proceedings of the 2018 International Conference on Energy and Mining Law.

Eni Muryani, "Sinergisitas Penegakan Hukum Pada Kasus Pertambangan Emas Tanpa Izin di Kabupaten Banyumas, Jawa Tengah”, Jurnal Bestuur, Volume 7, No. 2 (2019).

Belvage, R. H. (2016). Strategi Penambang Minyak Tradisional diTengah Meluasnya Kontrol Negara dalam Konteks Pengelolaan Sumber Daya Alam di Indonesia. Jurnal Masyarakat E Budaya, Volume 18 No. 3, 453-466.

Agung Marsudi D. Susanto, 2016 Chevronomics, Oil Company, Oil Service, Awas Kompeni !. Jakarta : Quantum.

Andrian Sutedi, 2011, Hukum Pertambangan, Jakarta : Sinar Grafika Offset,.

Anton A. Lailossa, “Kesiapan Pemerintah Daerah Dalam Mengelola PI $10 \%$, Materi Webinar 6 Juli 2020

Abdul Kadir Jaelani, "Politik Hukum Putusan Mahkamah Konstitusi Nomor 36/PUU-X/2012 Tentang Pembubaran BP MIGAS: Upaya Mengembalikan Kedaulatan Negara Menuju Perlindungan HAM”, Jurnal Panggung Hukum, Volume 1, Nomor 1 Tahun 2015.

Djufri Rays Pattilouw, "Dampak Ekonomi Pengelolaan Blok Masela”, materi webinar 6 Juli 2020.

Frankel, Jeffrey A., 2012, “The Natural Resource Curse: A Survey of Diagnoses and Some Prescriptions", makalah. 
Heller, Patrick dan Poppy Ismalina, “Transparansi dan Akuntabilitas Migas dan Pertambangan : Pertimbangan Untuk Pemerintahan Jokowi - JK”, dalam http:// www. google. co. id/?gws_rd=cr\&ei=756qV-6jG4vjvgSR-YT4CQ\#q= $\begin{array}{llll}\text { Survei+ } & \text { Indeks+ } & \text { Tata+Kelola+ }\end{array}$ (Resource+Governance+Index\%2FRGI)+atas+58+negara .

Heri Susanto, "Negara Terkaya-Termiskin di Dunia, Dimana Indonesia ? " dalam Vivanews.com, 22 September 2010, http://bisnis.news. viva.co.id/news/read/178888-negara-terkaya---termiskin--dimana-indonesia-,

I Gusti Ayu Ketut Rahmi Handayani dan Edi As'adi, 2019, Hukum Administrasi Negara Dalam Pengelolaan Sumber Daya Alam Dan Energi Berbasis Lingkungan, Depok : Rajawali Press.

Jarot Digdo Ismoyo, 2018, Politik Hukum Pertambangan Mineral Dan Batubara Berdasarkan Uud 1945 Dalam Mewujudkan Kesejahteraan Sosial”, Disertasi, Program Pascasarjana. Universitas Sebelas Maret.

Zaidah Nur Rosidah, "Coherence of the Rules of Sharia Against Pancasila”, Jurnal Bestuur, Volume 8, No. 1 (2020).

Rudy Iskandar Ichlas, "Questioning the Independence of Media Coverage in the 2019 Elections", Jurnal Bestuur, Volume 8, No. 1 (2020).

Triwanto Triwanto, Esti Aryani, "The Urgency of Granting Authority to Assess Corruption Justice Collaborators”, Jurnal Bestuur, Volume 8, No. 1 (2020).

Lego Karjoko, Zaidah Nur Rosidah, I Gusti Ayu Ketut Rahmi Handayani, "Refleksi

Paradigma Ilmu Pengetahuan Bagi Pembangunan Hukum Pengadaan Tanah”, Jurnal Bestuur, Volume 7, No. 1 (2019).

Marsel Selamat, 2018, Hukum Sumber Daya Alam Indonesia, dari Era Kolonial Sampai Otonomi Daerah, Malang : Setara Press.

Abdul Kadir Jaelani, "Implementasi Daluarsa Gugatan Dalam Putusan Peradilan

Tata Usaha Negara di Indonesia”, Pena Justisia: Media Komunikasi dan Kajian Hukum, Volume 18, Nomor 2 Tahun 2019.

Abdul Kadir Jaelani, Alexander A Kurniawan, Lusia Indrastuti "Pelaksanaan Standarisasi Pemberian Paten Dalam Invensi Bidang Obat-Obatan Di Indonesia”, Legality: Jurnal Ilmiah Hukum, Volume 27, Nomor 2 Tahun 2019 Marwan Batubara, "Pengelolaan PI Blok Masela Untuk Kesejahteraan Rakyat Maluku Yang Berkeadilan", materi Webinar 6 Juli 2020.

Moh. Mahfud M.D., 2014, Politik Hukum di Indonesia, Edisi Revisi, Cet. 6, Rajawali Press, Jakarta.

Mohammad Hatta, 2015, Politik, Kebangsaan, Ekonomi, 1926-1977, penebit Kompas, Jakarta.

Nanik Trihastuti, 2013, Hukum Kontrak Karya, Pola Kerjasama Pengusahaan Pertambangan di Indonesia, Malang : Setara Press, ctk. Pertama. 